\title{
Performance of Soybean in Guyana's Peats and Peaty Clays ${ }^{1}$
}

\begin{abstract}
Abdul H. Wahab
ABSTRACT

Results of preliminary studies indicate that given adequate drainage, fertilizers and good crop and soil management, Guyana's agriculturally poor Anira peat $\# 20$ and Inki clay $\# 100$ can produce yields of 2.0 to 2.4 tons/ha of excellent quality soybean seeds. Despite the extreme acidity, nodulation was satisfactory in both soils. Effects of residual vs. supplemental additions of NPK on successive crop yields are discussed.
\end{abstract}

\section{INTRODUCTION}

Peats and peaty clays constitute about one million hectares at present undeveloped in Guyana ${ }^{3}$. Two of these soils are classified locally as Anira peat \#20 and Inki clay \#100 (2). These soils are agriculturally poor and, unless drained, flooded most of the year. However, when adequately drained and properly fertilized they may be used for commercial agriculture. In some instances two crops are produced per year in organic soils of the United States ${ }^{4}$. In Guyana, the Anira peats and Inki clays are extremely acid and low in phosphorus and potassium. However, they possess certain outstanding characteristics which favour their use for agriculture. These soils are quite coarse or medium to fine-structured; are light (having bulk densities varying from 0.25 to 0.95 ) compared with mineral soils; have high water holding capacities; are porous, open and easy to cultivate. These characteristics make peats especially desirable for production of short-season crops.

The objectives of the present study were to conduct preliminary observations on the suitability of these soils for soybean production. Soybean was chosen as the test crop because of its importance as a source of edible oils and livestock feed both of which must be imported to satisfy present local needs.

\section{MATERIALS AND METHODS}

Both test soils were sampled prior to the trials and analyzed for relevant chemical and physical properties. Results are presented in table

${ }^{1}$ Manuscript submitted to Editorial Board November 2, 1978.

${ }^{2}$ Former Crop Development Officer, Project Evaluation Unit, Guyana Sugar Corporation Ltd., now Specialist in Agricultural Research, Inter-American Institute of Agricultural Sciences, OAS, Kingston, Jamaica.

${ }^{3}$ Steele, J. G. and Ramdin, H. N., 1975. Soil resources of Guyana, Ministry of Agriculture, Central Agricultural Station, Mon Repos.

${ }^{4}$ Buckman H. O. and Brady, N. C., 1969. The nature and properties of soils, the Macmillan Co., New York, N.Y. 
1. Anira peat $\# 20$ consists of dark reddish brown peat from the surface to an auger depth of $122 \mathrm{~cm}$; hydrogen sulphide was detected throughout this soil layer. Anira peat has a high swell/shrink ratio (50\% or greater) and is susceptible to spontaneous combustion when dry. Inki clay \#100 consists of a surface matt of 1-20 cm of peaty clay. The upper subsoil is a soft gray to greenish gray clay which is underlain by peat.

Both soils are extremely acid ( $\mathrm{pH}$ 3.7-4.2) and possess high buffering capacities (44-53\% base saturation). Water holding capacity of Anira peat is distinctly greater than that of Inki clay and amounted to three times

TABLE 1.-Physicochemical properties of two marginal soils used for growing soybeans at Enmore Sugar Estate

\begin{tabular}{|c|c|c|c|c|}
\hline & \multicolumn{2}{|c|}{$\begin{array}{c}\text { Anira peat } \# 20 \text { Soil layer } \\
(\mathrm{cm})\end{array}$} & \multicolumn{2}{|c|}{ Inki clay \#100 Soil layer $(\mathrm{cm}$} \\
\hline & $0-15$ & $15-30$ & $0-15$ & $15-30$ \\
\hline \multicolumn{5}{|l|}{ Mechanical analysis: } \\
\hline Clay, \% & 12 & - & 63 & - \\
\hline Silt, \% & 22 & - & 24 & - \\
\hline Sand, $\%$ & 14 & - & 3 & - \\
\hline Field capacity at $1 / 3 \mathrm{bar}, \%$ & 299 & - & 58.7 & - \\
\hline Bulk density, $\mathrm{g} / \mathrm{cm}^{3}$ & 0.24 & 0.22 & 0.94 & 0.94 \\
\hline $\mathrm{pH}(1: 2.5)$ & 3.71 & 3.58 & 4.21 & 4.14 \\
\hline Conductivity, $\mathrm{p} / \mathrm{m}$ & 861 & 932 & 647 & 830 \\
\hline CEC, Meq/100 $\mathrm{g}^{1}$ & 18.23 & 22.32 & 15.49 & 16.79 \\
\hline \multicolumn{5}{|l|}{ Cations, Meq/100 g } \\
\hline $\mathrm{Ca}^{++}$ & 4.43 & 3.55 & 2.96 & 2.64 \\
\hline $\mathrm{Mg}^{++}$ & 5.26 & 7.99 & 3.39 & 5.43 \\
\hline $\mathrm{Al}^{++}$ & 7.37 & 7.44 & 8.60 & 8.07 \\
\hline $\mathrm{K}^{+}$ & 0.52 & 0.38 & 0.32 & 0.30 \\
\hline $\mathrm{Na}^{+}$ & 0.68 & 1.03 & 0.23 & 0.35 \\
\hline Base saturation, $\%$ & 53.6 & 53.0 & 36.9 & 51.5 \\
\hline Phosphorus, $\mathrm{p} / \mathrm{m}$ & 37.5 & 15.25 & 1.47 & 0.77 \\
\hline Nitrogen, \% & 1.49 & 1.43 & 0.54 & 0.40 \\
\hline Organic matter, \% & 31.4 & 33.5 & 8.1 & 7.1 \\
\hline $\mathrm{C} / \mathrm{N}$ ratio & 12.4 & 14.3 & 7.2 & 10.0 \\
\hline
\end{tabular}

' $\mathrm{Ca}, \mathrm{Mg}$ and $\mathrm{Al}$ were determined using $\mathrm{N} \mathrm{KCL}$ extract. $\mathrm{K}$ and $\mathrm{Na}$ were determined using $0.5 \mathrm{~N} \mathrm{CH}_{3} \mathrm{COOH}$ extract.

its dry weight. Conversely, bulk densities of Anira peat approximate onefourth, 0.23 ; those of Inki clay, 0.94. Levels of soluble salts within both soils are within the tolerance range for most crops. Both soils tested are low in available phosphorus; potassium was moderately adequate for plant growth. Total nitrogen in either soil appeared to be adequate for a leguminous crop. $\mathrm{N}$ ratios were satisfactory, 13, for Anira peat but low, 8.5, for Inki clay. 
The trial site is located $10 \mathrm{~km}$ south of Enmore Sugar Mill. Two experiments were conducted from June 1975 to May 1976. Experiment 1 was conducted to determine soybean seed yields on fertilized and limed plots vs. control plots. At sowing, fertilized plots received $\mathrm{P}$ and $\mathrm{K}$ in amounts equivalent to those contained in a 3 tons/ha seed yield. This amounted to $37 \mathrm{~kg} / \mathrm{ha} \mathrm{P}$ as $\mathrm{P}_{2} \mathrm{O}_{5}$ and $112 \mathrm{ka} / \mathrm{ha} \mathrm{K}$ as $\mathrm{K}_{2} \mathrm{O}$. Nitrogen was applied as urea at the rate of $56 \mathrm{Kg} / \mathrm{ha}$. To ameliorate soil acidity, 9 tons/ ha of lime were applied as aragonite with the N,P,K mixture. Due to their unavailability, trace elements were not applied.

Following the results of experiment 1, a second planting was sown (experiment 2) to determine the effects on yield of: 1) residual $\mathrm{N}, \mathrm{P}$ and $\mathrm{K}$ from the previous crop; and 2) a supplemental application of N, P and $\mathrm{K}(11.2 \mathrm{~kg} / \mathrm{ha} \mathrm{N}, 12.3 \mathrm{~kg} / \mathrm{ha} \mathrm{P}$ and $37.3 \mathrm{~kg} / \mathrm{ha} \mathrm{K}$ ) to previously fertilized plots. Also, a third treatment was included to measure seed yields of previously unfertilized (control) plots following liming and fertilization at rates similar to those used in experiment 1 . All plots received $45 \mathrm{~kg} / \mathrm{ha}$ of fritted trace elements containing $\mathrm{B}, \mathrm{Cu}, \mathrm{Fe}, \mathrm{Mn}, \mathrm{Mo}$ and $\mathrm{Zn}$.

Following drainage and land clearing, plots were ploughed and rotavated. The test areas measured $30.5 \mathrm{~m}^{2}(0.09 \mathrm{ha})$ on Inki Clay and $76 \times$ $10 \mathrm{~m}$ (0.07 ha) on Anira peat. The sites were within $300 \mathrm{~m}$ of each other and serviced by an adequate drainage system.

Experiment 1 was planted June 12, 1975, and harvested 119 days thereafter (October 8). At sowing, feritlizers and lime were banded $5 \mathrm{~cm}$ from the seed and incorporated 7.5 to $10 \mathrm{~cm}$. Soybean seeds (Glycine $\max (\mathrm{L})$ Merill), Jupiter variety, were used for these studies.

Seeds (95\% viable) were slurry treated with inoculant (2 kg Nitragin/ $100 \mathrm{~kg}$ seed) and Dithane M- $45^{5}(0.18 \mathrm{~kg}$ a.i. $/ 100 \mathrm{~kg} / \mathrm{seed})$ and planted 5$6 \mathrm{~cm}$ deep in furrows $51 \mathrm{~cm}$ apart. Just prior to emergence of the second trifoliates, stands were thinned to 20 plants per meter of row $(390,260$ / ha). There was no need for weed control. However, following flowering and continuing through seed filling, there were fortnightly applications of Monocrotophos (0.5 liter a.i./ha) to control leaf and pod chewing insects.

Experiment 2 was planted January 19 and harvested May 12, 1975 (113 days). Seeds from crop 1 (95\% viable) were treated and planted in a similar manner to that used for experiment 1 . Wherever applicable, fertilizers and lime were broadcast and disced into the $0-15 \mathrm{~cm}$ soil depth October 30, 1975. Planting was delayed, due to adverse weather, until January 19,1976 . No weeding nor pest control program was necessary for this second crop.

\footnotetext{
${ }^{5}$ Trade names in this publication are used only to provide specific information. Mention of a trade name does not constitute a warranty of equipment or materials by the Agricultural Experiment Station of the University of Puerto Rico, nor is this mention a statement of preference over other equipment or materials.
} 
In experiment 1, test plots were examined for nodulation at flowering. At maturity (95 per cent ripe pods), plant height and podding scores were recorded. The distance from the ground surface to the tip of main stem was considered as plant height. For experiment 2, nodulation scores and nodule dry weight were recorded at flowering and also 3 weeks thereafter. Plant height and podding score were also recorded at maturity. For each observation, five sets of 25 randomly chosen plants were sampled. Grain yields were determined from 5-10 meter long test rows, replicated five times. Yields and 100-seed weights are expressed at $12 \%$ moisture. Throughout the trial, a record of daily rainfall was kept at the experimental sites.

\section{RESULTS AND DISCUSSION}

\section{CROP 1}

A total of $91 \mathrm{~cm}$ of rain fell during the trail. Rainfall was heaviest in July $(44 \mathrm{~cm})$ which coincided with flowering and pod set; and lowest in

TABLE 2.-Agronomic data for soybeans (variety Jupiter) grown on fertilized and unamended Inki clay \#100 and Anira peat \#20 plots at Enmore Sugar Estate from June 12 to October $8^{1}$

\begin{tabular}{|c|c|c|c|c|c|c|}
\hline Soil type & Treatment & $\begin{array}{l}\text { Mean } \\
\text { yield }^{2}\end{array}$ & Pods/plant & $\begin{array}{c}100 \text {-seed } \\
\text { weight }\end{array}$ & $\begin{array}{l}\text { Nodules/ } \\
\text { plant }\end{array}$ & $\begin{array}{l}\text { Height at } \\
\text { maturity }\end{array}$ \\
\hline & & (Tons/ha) & No. & $G$ & No. & $\mathrm{Cm}$ \\
\hline \multirow[t]{2}{*}{ Anira peat $\# 20$} & Fertilized & $0.94^{\mathrm{b} 3}$ & $6^{\mathrm{b}}$ & $13.6^{\mathrm{b}}$ & $17^{\mathrm{b}}$ & $58^{\mathrm{b}}$ \\
\hline & Unamended & 0 & 0 & 0 & 0 & 0 \\
\hline \multirow[t]{2}{*}{ Inki clay $\# 100$} & Fertilized & $2.37^{\mathrm{c}}$ & $18^{\mathrm{c}}$ & $17.3^{\mathrm{c}}$ & $22^{c}$ & $56^{\mathrm{b}}$ \\
\hline & Unamended & $0.04^{\mathrm{a}}$ & $2^{\mathrm{a}}$ & $11.3^{\mathrm{a}}$ & $10^{\mathrm{a}}$ & $33^{\mathrm{a}}$ \\
\hline
\end{tabular}

'All values are the means of five observations.

${ }^{2}$ Yields and seed size are expressed at $12 \%$ moisture.

${ }^{3}$ Values in columns followed by the same letter do not differ significantly at $p>0.05$.

September $(9 \mathrm{~cm})$ when the crop was undergoing seed filling and maturation. At no time during the trial were plots flooded, nor were symptoms of water stress evident.

Irrespective of soil and treatment, germination and early stand establishment were excellent. However, control plots on the Anira peat suffered total annihilation following browning and subseqeunt collapse of epicotyls and petioles at the first trifoliate leaf stage. This situation apparently resulted from a combination of low soil calcium (table 1) and unavailability of secondary plant nutrients which normally occurs in extremely acid soils. Stands on the controlled Inki clay plots were also excellent prior to emergence of the first trifoliates. Thereafter, growth was stunted and leaves were abnormal, again indicative of non-optimum balance of plant nutrients. 
Plant growth on the fertilized and limed plots was equally good on both soils (table 2). At maturity, plants were $58 \mathrm{~cm}$ tall on Anira peat and 56 $\mathrm{cm}$ on Inki clay. However, pod set and nodulation score were significantly greater on Inki clay than on Anira peat.

Grain yields were negligible $(40 \mathrm{~kg} / \mathrm{ha})$ on the control Inki clay plots. However, fertilized and limed plots produced an impressive yield of 2,370 $\mathrm{kg} / \mathrm{ha}$ on Inki clay vs. $940 \mathrm{~kg} / \mathrm{ha}$ on Anira peat. Also, seeds were $27 \%$ larger (17.3 g/100 seed) on the Inki clay plots than on similarly treated Anira peat plots (13.6 g/100 seed). Seed quality from fertilized plots on both soils was excellent. Following harvest, seeds were found to be $98 \%$ viable. At maturity, crop stand was erect on the Inki clay plots but moderately severe lodging was observed on the Anira peat plot.

\section{CROP 2}

Rainfall recorded for the duration of the trial amounted to $870 \mathrm{~mm}$. Heaviest rains occurred at the onset of flowering (late February). During pod set and seed filling $310 \mathrm{~mm}$ of rain fell at the trial site. Due to a protracted wet period which delayed harvest by one week, seeds were slightly deteriorated at harvest.

Table 3 shows seed yields and other agronomic characteristics for the various plots on both soils. Previously fertilized Anira peat plots that yielded $940 \mathrm{~kg} / \mathrm{ha}$ in the first instance produced mean yields of $2080 \mathrm{~kg} /$ ha (33 bushels/acre) in the consecutive crop when trace elements only were added. Yields were also highest compared to plots that had received a full dose of $\mathrm{N}, \mathrm{P}, \mathrm{K}$ or those that had received an $\mathrm{N}, \mathrm{P}, \mathrm{K}$ supplement prior to planting. Irrespective of plot, seeds were of excellent quality at maturity and averaged $20.5 \mathrm{~g} / 100$ seed, compared to $13.6 \mathrm{~g} / 100$ seed in the previous crop. Nodule number and weight per root were greater at 3 weeks from floral initiation than at the onset, and were significantly greater for treatment 1 than for the others.

On Inki clay, the highest yielding plot was that receiving a full dose of $\mathrm{N}, \mathrm{P}, \mathrm{K}$ and lime plus trace elements at sowing. Yields averaged $2390 \mathrm{~kg} /$ ha compared with $2370 \mathrm{~kg} / \mathrm{ha}$ obtained from similarly fertilized and limed plots in crop 1. Plots receiving no additional N, P and K yielded $2040 \mathrm{~kg} /$ ha (32.5 bushels/acre) and those receiving an $\mathrm{N}, \mathrm{P}, \mathrm{K}$ supplement produced $2260 \mathrm{~kg} / \mathrm{ha}$ (36 bushels/acre) excellent quality seeds. When analyzed, yield data did not differ statistically among treatments 1,2 and 3 at the $5 \%$ probability level.

Seeds were significantly larger in plots receiving a full dose of $N, P, K$ $(22.2 \mathrm{~g} / 100$ seed) and smallest in plots tested for residual effects of N, P and $\mathrm{K}$ on yield ( $18.5 \mathrm{~g} / 100$ seed).

These results indicate that given adequate drainage, rational fertilization and good crop management, sustained yields of $2220 \mathrm{~kg} / \mathrm{ha}$ and 1550 
TABLE 3.-Agronomic data for soybean (variety Jupiter) grown (January 19 to May 12, 1976) on two agriculturally poor soils at Enmore Sugar Estate. ${ }^{1}$

\begin{tabular}{|c|c|c|c|c|c|c|c|c|c|}
\hline \multirow{3}{*}{ Soil type } & \multirow{3}{*}{ Treatment } & \multirow{3}{*}{$\begin{array}{l}\text { Mean yield }{ }^{2} \\
(\text { ton } / \mathrm{ha})\end{array}$} & \multicolumn{4}{|c|}{ Nodule } & \multirow{3}{*}{ Pods/plant } & \multirow{3}{*}{$\begin{array}{l}\text { Height at matu- } \\
\text { rity }(\mathrm{cm})\end{array}$} & \multirow{3}{*}{$\begin{array}{l}100 \text { seed wt } \\
(\mathrm{g})\end{array}$} \\
\hline & & & \multicolumn{2}{|c|}{ Number/plant } & \multicolumn{2}{|c|}{ Dry wt. mg/plant } & & & \\
\hline & & & Date 1 & Date 2 & Date 1 & Date 2 & & & \\
\hline \multirow[t]{3}{*}{ Anira peat $\# 20$} & $1^{3}$ & $2.08^{\text {nst }}$ & $18^{\mathrm{ns}}$ & $34^{\mathrm{h}}$ & $66^{\mathrm{a}}$ & $152^{\mathrm{c}}$ & $18^{\mathrm{h}}$ & $54^{n+1}$ & $19.5^{\mathrm{nx}}$ \\
\hline & $2^{4}$ & 1.90 & 19 & $26^{\mathrm{a}}$ & $71^{\mathrm{b}}$ & $140^{h}$ & $17^{\mathrm{b}}$ & 52 & 20.7 \\
\hline & $3^{5}$ & 1.68 & 19 & $28^{a}$ & $67^{\mathrm{a}}$ & $116^{\mathrm{a}}$ & $13^{\mathrm{a}}$ & 52 & 21.4 \\
\hline \multirow[t]{3}{*}{ Inki clay \#100 } & 1 & $2.04^{\mathrm{ns}}$ & $18^{\mathrm{a} 7}$ & $22^{\mathrm{a}}$ & $59^{\text {ns }}$ & $85^{\mathrm{n} \mu}$ & $14^{\mathrm{ns}}$ & $52^{\text {ns }}$ & $18.5^{\mathrm{a}}$ \\
\hline & 2 & 2.26 & $18^{\mathrm{a}}$ & $21^{\mathrm{a}}$ & 63 & 111 & 13 & 52 & $19.5^{\mathrm{a}}$ \\
\hline & 3 & 2.39 & $21^{b}$ & $27^{b}$ & 75 & 140 & 13 & 50 & $22.2^{\mathrm{b}}$ \\
\hline
\end{tabular}

${ }^{1}$ All values are the means of five observations.

${ }^{2}$ Yields and seed size are expressed at $12 \%$ moisture.

${ }^{3}$ Plots were limed ( 9 ton/ha aragonite) and fertilized ( $56 \mathrm{~kg}, \mathrm{~N}, 37 \mathrm{~kg} \mathrm{P}$ and $112 \mathrm{~kg} / \mathrm{ha} \mathrm{K}$ ) immediately preceding planting of the first crop in June 1975. For this crop, except for the application of $45 \mathrm{~kg} / \mathrm{ha}$ of fritted trace elements, lime and fertilizers were withheld.

${ }^{4}$ Plots were treated similarly as in treatment 1 for the first sowing. For the second crop, plots received $11.2 \mathrm{~kg} \mathrm{~N}, 12.3 \mathrm{~kg} \mathrm{P}, 37.3 \mathrm{~kg} \mathrm{~K}$ and $45 \mathrm{~kg} / \mathrm{ha}$ fritted trace elements.

${ }^{5}$ These plots had been unfertilized and unlimed prior to this crop. Before planting, 9 ton/ha aragonite, $56 \mathrm{~kg} \mathrm{~N}, 37 \mathrm{~kg} \mathrm{P}, 112 \mathrm{~kg} \mathrm{~K}$ and 45 $\mathrm{kg} / \mathrm{ha}$ fritted trace elements were broadcast and disced into the $0-15 \mathrm{~cm}$ soil layer.

${ }^{6}$ Statistical analyses of the data revealed no significant difference at $p>0.05$.

${ }^{7}$ Means in columns for a given soil type followed by the same letter do not differ significantly at $\mathrm{p}>0.05$. 
$\mathrm{kg} / \mathrm{ha}$ of excellent quality seeds can be obtained over two consecutive crops from Guyana's agriculturally peaty clays and peats.

Benefits from fertilizers are unquestionable in both soils but there appears to be a delayed response in Anira peat compared to that in Inki clay. This is probably due to higher fixation rates of applied $\mathrm{P}$ in Anira peat than on Inki clay as would be expected to occur at a soil $\mathrm{pH}$ of 3.7 vs. 4.1 for the Inki clay. Also, at planting of the first crop, the Anira peat was quite "raw and fibrous" but at harvest of the second crop, 9 mo later, this soil was observed to have undergone marked decomposition. This was evidenced by a change in color from reddish brown to almost black and from coarse to medium-structured at the beginning of the trial to medium to fine-structured following the harvest of the second crop. It is plausible that as the soil became oxidized, soil reaction was improved and mineralization rates of $\mathrm{N}$ and $\mathrm{P}$ were enhanced.

In addition to having demonstrated that these soils can be cropped to soybean, it is worthwhile pointing out that once drained, cleared and tilled, subsequent land tillage is minimal on Inki clay and may not be necessary at all on Anira peat. This is because the soils are light, loose, highly porous and do not become compacted as readily as the heavy coastal clays do. If studies of these soils are to continue with the ultimate objective of developing them for agriculture, efforts should be directed to solve soil fertility and soil management problems, and to discover adaptability of other short-season crops.

\section{RESUMEN}

Los resultados de los estudios preliminares que aquí se informan señalan el potencial de los suelos clasificados como Turba Anira \#20 e Inki arcilloso \#100 para la producción de soyas. En Guyana, estos suelos se consideran pobres desde el punto de vista agrícola. Se lograron rendimientos de 2 a $2.4 \mathrm{~T} /$ ha de calidad excelente cuando se siguieron prácticas agrícolas adecuadas incluyendo desagüe, abonamiento y cultivo. A pesar de la extrema acidez de los suelos, la nodulación fue excelente. En este trabajo se discute el efecto residual de aplicaciones de NPK vs. aplicaciones suplementarias en los rendimientos de las cosechas subsiguientes. 